\title{
Faktor-Faktor yang Mempengaruhi Struktur Modal pada Perusahaan Pertambangan di Bursa Efek Indonesia Periode 2015-2018
}

\author{
Nurul Aryanti ${ }^{1 *}$, Riana R Dewi ${ }^{2}$, Purnama Siddi ${ }^{3}$ \\ ${ }_{1,2,3}$ Universitas Islam Batik Surakarta, JL. KH Agus Salim No. 11, Surakarta \\ *Correspondence email: nurulyanti264@gmail.com, ${ }^{2}$ riana_rd40@yahoo.co.id, ${ }^{3}$ purnama.siddi@yahoo.com
}

\begin{abstract}
Absract. This study examines and analyzes the factors that influence capital structure. Independent variables in this study are company size, liquidity, profitability and asset structure. The population in this study are mining companies listed on the Indonesia Stock Exchange for the 2015-2018 period. The sample selection technique uses purposive sampling and 12 company samples are obtained within a period of 4 years so that 48 company samples are obtained. The data analysis method used in this study is panel data regression. Hypothesis testing is done using the $t$ test and the $F$ test. The panel data regression test results show that simultaneously company size, liquidity, profitability and asset structure have an influence on capital structure. While partially the variables that significantly influence the capital structure are company size. While the liquidity, profitability and asset structure variables do not significantly affect the capital structure.
\end{abstract}

Keywords: Company Size, Liquidity, Profitability, Asset Structure, Capital Structure.

\section{PENDAHULUAN}

Seiring dengan meningkatnya persaingan dalam era globalisasi yang semakin maju, setiap perusahaan dituntut untuk mampu menyesuaikan dengan keadaan yang terjadi dan melakukan pengelolaan terhadap fungsi-fungsi penting yang ada dalam perusahaan sehingga perusahaan dapat lebih unggul dalam persaingan yang akan dihadapi. Dalam kondisi era globalisasi saat ini akan menimbulkan persaingan usaha yang semakin ketat, terlebih lagi saat ini Indonesia sudah memasuki era Asean Economic Comunity (AEC) atau bisa disebut dengan Masyarakat Ekonomi Asean (MEA). Ini nantinya memungkinkan satu negara menjual barang dan jasa dengan mudah ke negara-negara lain di seluruh Asia Tenggara sehingga kompetisi akan semakin ketat. Mengingat perusahaan Pertambangan juga memberikan kontribusi yang cukup besar bagi negara, maka dirasa perlu untuk mengkaji perusahaan Pertambangan dalam penelitian ini. Dunia pertambangan Indonesia memiliki profil yang sangat luar biasa. Indonesia menduduki peringkat 6 besar dunia dalam hal kepemilikan bahan-bahan tambang. Indonesia kaya dengan sumber daya alam khususnya bahan tambang. Selain itu, dari potensi bahan galiannya untuk batubara, Indonesia menduduki peringkat ke-3 untuk ekspor batubara, peringkat ke2 untuk produksi timah, peringkat ke-2 untuk produksi tembaga, peringkat ke-6 untuk produksi emas. Sektor pertambangan masih jadi andalan pemerintah dalam penerimaan negara untuk APBN. Sektor ini bisa menyumbangkan Penerimaan Negara Bukan Pajak (PNBP) mencapai Rp 43 triliun pada akhir tahun ini.

Pertambangan merupakan sektor yang sensitif terhadap perekonomian dunia. Di Indonesia, sektor pertambangan termasuk sektor yang sangat berpengaruh terhadap perekonomian Indonesia. Tahun 2015, ekspor pertambangan dan lainnya mengalami penurunan sebesar 5,23\% dari tahun 2016. Kenaikan ekspor juga terjadi pada tahun 2016 dan 2018 yaitu sebesar 34,38\% dan 25,56\%. Harga Patokan Ekspor (HPE) produk pertambangan mengalami kenaikan maupun penurunan yang disebabkan oleh fluktuasi harga internasional. Fluktuasi harga internasional mempengaruhi penetapan HPE. Penurunan ekspor tersebut disebabkan oleh berkurangnya permintaan impor batubara dan mineral dari global terhadap Indonesia. Hasil penelitian sebelumnya tentang faktor ukuran perusahaan, likuiditas, profitabilitas dan struktur aktiva telah banyak dilakukan seperti Yusron et all (2016), Lasut et all (2018), Tijow et all (2018) menyimpulkan bahwa ukuran perusahaan berpengaruh terhadap struktur modal, akan tetapi temuan penelitian Halim (2018) berbeda dengan hasil sebelumnya. Temuan Dahlena (2017) dan Dwija Bhawa \& Made (2015) menyatakan bahwa likuiditas memiliki pengaruh terhadap stuktur modal. Hasil penelitian yang dilakukan oleh Kharizmatullah et all (2017) dan Acaravci (2015) menyimpulkan bahwa profitabilitas memiliki pengaruh terhadap struktur modal, sedangkan menurut Lasut et all (2018) profitabilitas sendiri tidak memiliki pengaruh terhadap struktur modal. Penelitian yang dilakukan oleh Dewiningrat \& Mustanda (2018) menyimpulkan bahwa struktur aktiva berpengaruh terhadap struktur modal, akan tetapi temuan penelitian Wardani (2015) berbeda dengan hasil penelitian sebelumnya.

\section{METODE}

Jenis penelitian ini adalah penelitian kuantitatif. Penelitian kuantitatif adalah data penelitian yang berlandaskan terhadap filsafat positivisme, digunakan dalam meneliti terhadap sampel dan populasi penelitian, teknik pengambilan sampel pada umumnya dilakukan purposive sampling (Sugiyono, 2015). Variabel dependen yang digunakan dalam penelitian ini adalah struktur modal. Struktur modal adalah perbandingan antara hutang jangka panjang dan modal 
sendiri yang digunakan perusahaan (Bambang \& Riyanto, 2001). Metode pengukuran yang digunakan yaitu DER (Debt to Equity Ratio) yang merupakan perbandingan antara total hutang perusahaan dengan total ekuitas. Rasio ini bergunak untuk mengetahui jumlah dana yang disediakan peminjam (kreditor) dengan pemilik perusahaan atau untuk mengetahui jumlah rupiah modla sendiri yang dijadikan untuk jaminan uang. Diukur dengan rumus :

Struktur modal $=\frac{\text { Total Hutang }}{\text { Total Ekuitas }}$

Variabel independen dalam penelitian ini adalah :

\section{Ukuran Perusahaan}

Ukuran perusahaan merupakan ukuran atau besarnya aset yang dimiliki oleh perusahaan pada akhir tahun, yang diukur menggunakan lognatural (Ln) dari total aktiva (Brigham E. \& Houston, 2001), rumusnya adalah sebagai berikut: Size $=$ Ln $($ Total Aktiva)

\section{Likuiditas}

Likuiditas merupakan tingkat kemampuan perusahaan dalam memenuhi kewajiban jangka pendeknya dengan aktiva lancar yang di milikinya. CR (Current Ratio) di ukur dengan rumus sebagai berikut (Sartono, 2014).

$\mathrm{CR}=\frac{\text { Aktiva Lancar }}{\text { Kewajiban Lancar }}$

\section{Profitabilitas}

Suatu kemampuan perusahaan dalam menghasilkan laba dalam suatu periode tertentu. Untuk mengukur tingkat profitabilitas dalam pengukuran ini, digunakan rasio ROA (Return On Asset). Menurut Udayani (2013) ROA dapat dihitung dengan rumus :

4. Struktur Aktiva

$\mathrm{ROA}=\frac{\text { Laba setelah pajak }}{\text { Total aset }}$

Struktur aktiva merupakan perbandingan antara aktiva tetap terhadap total aktiva (Sudana, 2011). Skala perbandingan variabel struktur aktiva menggunakan skala rasio dengan rumus:

Struktur Aktiva $=\frac{\text { Aktiva Tetap }}{\text { Total Aktiva }}$

\section{HASIL}

Tabel 1

Hasil Uji Statistik Deskriptif

\begin{tabular}{llllll}
\hline & $\mathrm{Y}$ & $\mathrm{X} 1$ & $\mathrm{X} 2$ & $\mathrm{X} 3$ & $\mathrm{X} 4$ \\
\hline Mean & 0.003958 & 19.08535 & 0.019144 & 0.100156 & 0.614031 \\
Median & 0.001950 & 19.34975 & 0.017150 & 0.058700 & 0.648400 \\
Maximum & 0.022700 & 21.94310 & 0.043000 & 0.394100 & 0.914200 \\
Minimum & 0.000300 & 13.97960 & 0.003100 & 0.000200 & 0.005100 \\
Std. Dev. & 0.004919 & 1.786196 & 0.009694 & 0.101769 & 0.215297 \\
Obs. & 48 & 48 & 48 & 48 & 48 \\
\hline
\end{tabular}

Sumber: data olahan

Berdasarkan perhitungan penelitian, diperoleh hasil sebagai berikut:

Variabel struktur modal (DER) memiliki nilai minimum sebesar 0,000300 terdapat pada perusahaan PT Mitrabara Adiperdana Tbk di tahun 2015 dan nilai maksimum sebesar 0,022700 terdapat pada perusahaan PT Surya Esa Perkasa Tbk di tahun 2017. Rata-rata struktur modal 0,003958 pada standar deviasi 0,004919. Nilai rata-rata lebih besar dari standar deviasi yaitu $0,003958<0,004919$ yang mengartikan bahwa sebaran nilai struktur modal baik. Variabel ukuran perusahaan memiliki nilai minimum sebesar 13,97960 terdapat pada perusahaan PT Indo Tambangraya Megah Tbk di tahun 2015 dan nilai maksimum sebesar 21,94310 terdapat pada perusahaan PT Dian Swastatika Sentosa Tbk di tahun 2018. Rata-rata ukuran perusahaan 19,08535 pada standar deviasi 1.786196. Nilai rata-rata lebih besar dari standar deviasi yaitu 21,94315 > 19,08535 yang mengartikan bahwa sebaran nilai ukuran perusahaan baik. Variabel likuiditas (CR) memiliki nilai minimum sebesar 0,003100 terdapat pada perusahaan PT J Resource Asia Pasifik Tbk di tahun 2015 dan nilai maksimum sebesar 0,043000 terdapat pada perusahaan PT Samindo Resource Tbk di tahun 2016. Rata-rata 0,019144 pada standar deviasi 0,009694. Nilai rata-rata lebih besar dari standar deviasi yaitu 0,019144>0,009694 yang mengartikan bahwa sebaran nilai likuiditas baik. Variabel profitabilitas (ROA) memiliki nilai minimum sebesar 0,000200 terdapat pada perusahaan PT Surya Esa Perkasa Tbk di tahun 2016 dan nilai maksimum sebesar 0,394100 terdapat pada perusahaan PT Baramulti Suksessarana Tbk di tahun 2017. Rata-rata 0,100156 pada standar deviasi 0,101769. Nilai rata-rata lebih kecil dari standar deviasi yaitu $0,100156<0,101769$ yang mengartikan bahwa sebaran nilai profitabilitas tidak baik.

Variabel struktur aktiva memiliki nilai minimum sebesar 0,005100 terdapat pada perusahaan PT Indo 
Nurul Aryanti et al, Faktor-Faktor yang Mempengaruhi Struktur Modal pada Perusahaan Pertambangan di Bursa Efek Indonesia Periode 2015-2018

Tambangraya Megah Tbk di tahun 2017 dan nilai maksimum sebesar 0,914200 pada perusahaan PT J Resource Asia Pasifik Tbk di tahun 2015. Rata-rata 0,614031 pada standar deviasi 0,215297. Nilai rata-rata lebih besar dari standar deviasi yaitu 0,614031 > 0,215297 yang mengartikan bahwa sebaran nilai struktur aktiva baik.

\section{Pemilihan Model Estimasi}

Tabel 2

Hasil Uji Chow

\begin{tabular}{clll}
\hline \multicolumn{1}{c}{ Effect Test } & Statistic & d.f. & Prob. \\
\hline Cross-section F & 6.847838 & $(11,32)$ & 0.0000 \\
Cross-section Chi-square & 58.086578 & 11 & 0.0000 \\
\hline Sumber: data olan & & 11 & \\
\hline
\end{tabular}

Sumber: data olahan

Berdasarkan hasil pemilihan Uji Chow pada tabel diatas, nilai Cross Section F adalah sebesar 0.0000 yang berada kurang dari 0,05. Dengan demikian model regresi yang baik digunakan adalah Fixed Effect Model.

Tabel 3

Hasil Uji Hausman

\begin{tabular}{|c|c|c|c|}
\hline Test Summary & Chi-Sq. Statistic & Chi-Sq. d.f. & Prob. \\
\hline Cross-section random & 3.909293 & 4 & 0.4184 \\
\hline
\end{tabular}

Sumber: data olahan

Berdasarkan hasil pemilihan uji hausman pada tabel diatas, nilai Cross Sectioan Random adalah sebesar 0.4184 yang berada lebih dari 0,05. Dengan demikian model regresi yang baik digunakan adalah Random Effect

Tabel 4

Hasil Uji Lagrange Multiplier (LM)

\begin{tabular}{|l|l|l|l|}
\hline Breusch-Pagan & $\begin{array}{l}18.76121 \\
(0.0000)\end{array}$ & $\begin{array}{l}0.302241 \\
(0.5825)\end{array}$ & $\begin{array}{l}19.06345 \\
(0.0000)\end{array}$ \\
\hline
\end{tabular}

Sumber: data olahan

Berdasarkan hasil pemilihan uji Lagrange Multiplier pada tabel diatas, dapat dilihat bahwa nilai probabilitas Breusch-Pagan pada Cross-section One-sided adalah sebesar 0.0000 atau lebih kecil dari 0,05. Artinya, model yang dipilih adalah Random Effect Model.

\section{Hasil Regresi}

Tabel 5

Hasil Regresi Data Panel

\begin{tabular}{lll}
\hline Variable & Coefficient & Std. Error \\
\hline C & -0.024896 & 0.011645 \\
Uk. Perusahaan & 0.001277 & 0.000488 \\
Likuiditas & -0.005306 & 0.067831 \\
ROA & -0.004242 & 0.007680 \\
Struktur Aktiva & 0.008167 & 0.004418 \\
\hline
\end{tabular}

Sumber: data olahan

Berdasarkan tabel diatas, maka diperoleh persamaan regresi data panel sebagai berikut : $\mathrm{Y}=-0.024896+0.001277-0.005306-0.004242+0.008167$

Konstanta sebesar -0.024896 artinya variabel independen bernilai 0, maka tingkat perubahan struktur modal (DER) sebesar 0.024896. Koefisien ukuran perusahaan sebesar 0.001277 artinya setiap kenaikan pada variabel ukuran perusahaan sebesar satu stauan, dengan asumsi variabel lainnya dianggap konsta, akan menaikkan tingkat struktur modal (DER) sebesar -0.001277. Koefisien likuiditas (CR) sebesar - 0.005306 artinya setiap kenaikan pada variabel likuiditas sebesar satu satuan, dengan asumsi variabel lainnya dianggap konstan, akan menurunkan tingkat struktur modal (DER) sebesar 0.005306 . Koefisien profitabilitas (ROA) sebesar -0.004242 artinya setiap kenaikan pada variabel profitabilitas sebesar satu satuan, dengan asumsi variabel lainnya dianggap konstan, akan menurunkan tingkat struktur modal (DER) sebesar 0.004242 . Koefisien struktur aktiva sebesar 0.008167 artinya setiap kenaikan pada variabel struktur aktiva 
Nurul Aryanti et al, Faktor-Faktor yang Mempengaruhi Struktur Modal pada Perusahaan Pertambangan di Bursa Efek Indonesia Periode 2015-2018

sebesar satu satuan, dengan asumsi variabel lainnya dianggap konstan, akan menurunkan tingkat struktur modal (DER) sebesar -0.008167 .

Uji Kelayakan Model (Uji F)

Tabel 6

Hasil Kelayakan Model (Uji F)

\begin{tabular}{|llll|}
\hline R-squared & 0.205485 & Mean dependent var & 0.001308 \\
Adjusted R- squared & 0.131577 & S.D. dependent var & 0.002706 \\
S.E. of regression & 0.002522 & Sum squared resid & 0.000273 \\
F-statistic & 2.780271 & Durbin-Watson stat & 1.581724 \\
Prob (F- statistic) & 0.038550 & & \\
\hline
\end{tabular}

Berdasarkan hasil pengujian pada tabel di atas nilai Prob (F-section) sebesar 0.038550 lebih kecil dari taraf signifikan 0,05, maka model layak. Dapat disimpulkan bahwa model regresi data panel menunjukkan tingkatan secara serempak atau simultan ukuran perusahaan, likuiditas, profitabilitas dan struktur aktiva berpengaruh struktur modal sehingga model layak digunakan.

Uji Hipotesis (Uji t)

Tabel 7

Hasil Uji Hipotesis (Uji t)

\begin{tabular}{llllll}
\hline Variabel & t-Statistic & t-tabel & Prob. & Sign & Ket \\
\hline UKP & 2.616152 & $>2,018$ & 0.0122 & $<0,05$ & Ditolak \\
CR & -0.078227 & $<2,018$ & 0.9380 & $>0,05$ & Diterima \\
ROA & -0.552399 & $<2,018$ & 0.5835 & $>0,05$ & Ditolak \\
SA & 1.848525 & $<2,018$ & 0.0714 & $>0,05$ & Ditolak \\
\hline
\end{tabular}

Sumber: data olahan

Pengaruh ukuran perusahaan terhadap struktur modal.

Hasil uji hipotesis menunjukkan nilai t hitung < t tabel yaitu $2.616152>2,018$ dan nilai prob. $t-$ statistik sebesar $0.0122<0,05$ sehingga H0 diterima. Maka dapat disimpulkan bahwa variabel ukuran perusahaan berpengaruh terhadap struktur modal.

\section{Pengaruh likuiditas terhadap struktur modal}

Hasil uji hipotesis menunjukkan nilai -t hitung $>$-t tabel yaitu $-0.078227<2,018$ dan nilai prob. t- statistik sebesar 0,9380 < 0,05 sehingga H0 ditolak. Maka dapat disimpulkan bahwa likuiditas tidak berpengaruh terhadap struktur modal.

\section{Pengaruh profitabilitas terhadap struktur modal}

Hasil uji hipotesis menunjukkan nilai $-\mathrm{t}$ hitung $<-\mathrm{t}$ tabel yaitu $-0.552399<-2,018$ atau nilai prob. $\mathrm{t}$ - statistik sebesar 0,5835>0,05 sehingga H0 diterima. Maka dapat disimpulkan bahwa profitabilitas tidak berpengaruh terhadap struktur modal.

Pengaruh struktur aktiva terhadap struktur modal

Hasil uji hipotesis menunjukkan nilai $-\mathrm{t}$ hitung $<-\mathrm{t}$ tabel yaitu $1.848525>-2,018$ dan nilai prob. $\mathrm{t}$ - statistik sebesar $0.0714>0,05$ sehingga H0 diterima. Maka dapat disimpulkan bahwa variabel struktur aktiva tidak berpengaruh terhadap struktur modal.

Analisis Koefisien Determinasi (R2)

Tabel 8

Hasil Koefisien Determinasi (R2)

\begin{tabular}{llll}
\hline Model & R square & Adjusted R-squared & Keterangan \\
\hline 1 & 0.205485 & 0.131577 & $13.15 \%$ \\
\hline
\end{tabular}

Sumber: data olahan 
Berdasarkan tabel 8 dapat diketahui bahwa variabel dependen dalam hal ini struktur modal dapat dipengaruhi hanya sebesar $13.15 \%$ oleh variabel independen. Hal itu dapat dilihat dari nilai R-square sebesar 0,205485. Sedangkan sebesar $86.85 \%$ variabel dependen struktur modal dipengaruhi oleh variabel-variabel lain yang tidak dimasukkan ke dalam penelitian ini.

\section{Pembahasan}

\section{Pengaruh Ukuran Perusahaan Terhadap Struktur Modal}

Berdasarkan regresi data panel bahwa dalam penelitian ini menunjukkan ukuran perusahaan tidak berpengaruh terhadap struktur modal. Hal tersebut dapat disebabkan karena kesalahan dalam pengembalian keputusan pendanaan, manajemen perusahaan tidak mampu mengelola struktur modal perusahaan dengan optimal. Hasil penelitian ini sejalan dengan penelitan yang dilakukan oleh Halim (2018) yang menyatakan bahwa ukuran perusahaan tidak berpengaruh terhadap struktur modal. Hasil penelitian ini tidak sesuai dengan penelitian yang dilakukan oleh Lasut (2018) yang menyatakan bahwa ukuran perusahaan mempunyai pengaruh terhadap struktur modal.

\section{Pengaruh Likuiditas Terhadap Struktur Modal}

Berdasarkan regresi data panel bahwa dalam penelitian ini menunjukkan likuiditas yang diproksi dengan CR (Current Ratio) berpengaruh terhadap struktur modal, dimana jika semakin besar likuiditas maka semakin besar pula struktur modal dan jika semakin kecil likuiditas maka semakin kecil pula struktur modal. Semakin tinggi kemampuan perusahaan dalam mengembalikan kewajiban-kewajiban jangka pendeknya maka semakin likuid perusahaan tersebut sehingga kepercayaan dari kreditur meningkat dan mempermudah perusahaan memperoleh utang jangka panjangnya. Hasil penelitian ini sejalan dengan penelitian yang dilakukan oleh Dwija Bhawa \& Made (2015) dan Deviani \& Sudjarni (2018) yang menyatakan bahwa likuiditas berpengaruh terhadap struktur modal, tetapi tidak sejalan dengan penelitian yang dilakukan oleh Firmanullah (2017) dan Dahlena (2017).

\section{Pengaruh Profitabilitas Terhadap Struktur Modal}

Berdasarkan hasil regresi data panel pada penelitian ini menunjukkan bahwa profitabilitas yang diproksi dengan ROA (Return On Asset) tidak berpengaruh terhadap struktur modal. Hal ini menunjukkan bahwa perusahaan dengan tingkat profitabilitas yang tinggi akan cenderung mengurangi penggunaan utang karena menggunakan pendanaan internal seperti saldo laba sebagai prioritas pendanaan, sehingga dengan kenaikan ROA (Return On Asset) akan menurunkan struktur modal. Hasil penelitian ini sejalan dengan penelitian yang dilakukan oleh Tijow et all (2018) dan Firmanullah (2017), namun tidak sejalan dengan penelitian Denziana \& Yunggo (2017) yang menyatakan bahwa profitabilitas memiliki pengaruh terhadap struktur modal.

\section{Pengaruh Struktur Aktiva Terhadap Struktur Modal}

Berdasarkan hasil regresi data panel pada penelitian ini menunjukkan bahwa struktur aktiva berpengaruh terhadap struktur modal. Struktur aktiva adalah penentuan seberapa besar alokasi dana untuk masing-masing komponen aktiva yang digunakan dalam mengambil keputusan mengenai struktur modal. Hal ini menunjukkan bahwa semakin tinggi struktur aktiva yang dicerminkan melalui perbandingan antara aktiva lancar dengan aktiva tetap, maka struktur modal perusahaan akan semakin meningkat. Hasil penelitian yang tidak signifikan menunjukkan bahwa dalam mengambil keputusan untuk struktur modal, maka perusahaan pertambangan di BEI pada periode 2015-2018 tidak terlalu mempertimbangkan struktur aktiva dalam pengambilan keputusan struktur modal. Hasil ini sejalan dengan penelitian yang dilakukan oleh Acaravci (2015), Firmanullah (2017) dan Nita \& Hairul (2017) yang menunjukkan bahwa struktur aktiva tidak berpengaruh terhadap struktur modal. Namun penelitian ini tidak sejalan dengan penelitian Deviani \& Sudjarni (2018) yang menyatakan bahwa struktur aktiva berpengaruh terhadap struktur modal.

\section{SIMPULAN}

Dari hasil analisis data didapatkan bahwa ukuran perusahaan, likuiditas, profitabilitas dan struktur aktiva secara bersama-sama (simultan) berpengaruh terhadap struktur modal. Hasil uji hipotesis secara parsial menunjukkan bahwa:

a. Variabel ukuran perusahaan penelitian ini tidak berpengaruh terhadap struktur modal. Hal ini dikarenakan dengan besar kecilnya suatu perusahaan tidak mempengaruhi pendanaan terhadap struktur modal, karena dalam penggunaan sumber dana yang berasal dari modal sendiri atau hutang, tentu mempunyai biaya modal yang berbeda dengan tingkat resiko yang berbeda pula.

b. Variabel likuiditas penelitian ini berpengaruh terhadap struktur modal. Hal ini dikarenakan perusahaan yang memiliki tingkat aktiva lancar yang tinggi mempunyai sumber dana yang cukup besar, sehingga perusahaan lebih memilih menggunakan dana internalnya terlebih dahulu untuk membiayai perusahaannnya sebelum mengambil keputusan untuk menggunakan dana yang berasal luar. 
Nurul Aryanti et al, Faktor-Faktor yang Mempengaruhi Struktur Modal pada Perusahaan Pertambangan di Bursa Efek Indonesia Periode 2015-2018

c. Variabel profitabilitas penelitian ini tidak berpengaruh terhadap struktur modal. Hal ini terjadi karena apabila laba perusahaan semakin rendah, maka perusahaan cenderung menggunakan hutang lebih banyak.

d. Variabel struktur aktiva penelitian ini tidak berpengaruh terhadap struktur modal. Hal ini dikarenakan bahwa semakin tinggi struktur aktiva yang dicerminkan melalui perbandingan antara aktiva lancer dengan aktiva tetap, maka struktur modal perusahaan akan semakin meningkat.

\section{DAFTAR PUSTAKA}

Acaravci, S. (2015). The Determinants of Capital Structure: Evidence from the Turkish Manufacturing Sector. International Journal of Economics and Financial Issues, 2146-4138.

Berkman, A., \& Omer Iskenderoglu. (2016). Determinants of Capital Structure: The Evidence from European Energy Companies. International Journal of Business Administration Vol. 7, No. 6.

Dahlena, M. (2017). Pengaruh Likuiditas, Risiko Bisnis Dan Profitabilitas Terhadap Struktur Modal Pada Perusahaan Textile Dan Garment Yang Terdaftar Di Bursa Efek Indonesia. Jurnal Riset Akuntansi \& Bisnis Vol. 17 No. 2, 1693-7597.

Denziana, A., \& Eilien Delicia Yunggo. (2017). Pengaruh Profitabilitas, Struktur Aktiva, dan Ukuran Perusahaan terhadap Struktur Modal pada Perusahaan Real Estate dan Property yang Terdaftar di BEI Tahun 2015. Jurnal Akuntansi dan Keuangan, 51-67.

Deviani, M., \& Luh Komang Sudjarni. (2018). Pengaruh Tingkat Pertumbuhan, Struktur Aktiva, Profitabilitas, dan Likuiditas Terhadap Struktur Modal Perusahaan Pertambangan di BEI. E-Jurnal Manajemen Unud, Vol. 7, No. 3, 1222-1254.

Dewiningrat, A. I., \& I Ketut Mustanda. (2018). Pengaruh Likuiditas, Profitabilitas, Pertumbuhan Penjualan, Dan Struktur Aset Terhadap Struktur Modal. E-Jurnal Manajemen Unud, Vol. 7, No. 7, 3471-3501.

Dwija Bhawa, I., \& Made Rusmala Dewi S. (2015). Pengaruh Ukuran Perusahaan, Likuiditas, Profitabilitas, Dan Risiko Bisnis Terhadap Struktur Modal Perusahaan Farmasi. E-Jurnal Manajemen Universitas Udayana 4 (7), 1949-1966.

Firmanullah, D. (2017). Faktor-Faktor yang Mempengaruhi Struktur Modal di Perusahaan Indonesia (Pada Perusahaan Manufaktur yang Terdaftar di BEI Tahun 2011-2014). Diponegoro Journal of Accounting, 6(3) 1-9.

Halim , P. (2018). Pengaruh Ukuran Perusahaan, Pertumbuhan Penjualan dan Risiko Bisnis Pada Struktur Modal . E-Jurnal Akuntansi Universitas Udayana Vol.23.3., 2391-2413 .

Harahap, S. (2011). .Teori Akuntansi Edisi Revisi 2011.

Horne, James. C. Van, \& John. M Wachowicz. (2009). Fundamentalsof Financial Managemen Prinsip-prinsip Manajemen Keuangan. Buku 1.Edisi 12.

Kartika, A. (2009). Faktor-Faktor Yang Mempengaruhi Struktur Modal Pada Perusahaan Manufaktur Yang Go Public Di BEI. Dinamika Keuangan dan Perbankan, Vol 1(2), Hal. 105-122.

Kesuma, A. (2009). Analisis Faktor yang Mempengaruhi Struktur Modal serta Pengaruhnya terhadap Harga Saham Perusahaan Real Estate yang GO-Public di Bursa Efek Indonesia . Jurnal Manajemen dan Kewirausahaan Vol. 11 No.1, Hal 38-45.

Lasut, S., Paulina Van Rate, \& Michael Ch. Rainting. (2018). Pengaruh Ukuran Perusahaan, Profitabilitas, Dan Likuiditas Terhadap Struktur Modal Pada Perusahaan Otomotif Yang Terdaftar Di Bursa Efek Indonesia Periode 2012-2015. Jurnal EMBA Vol 6 No 1, 2303-1174.

Nita, N., \& Anam Hairul. (2017). Analisis Faktor-faktor yang Mempengaruhi Struktur Modal Perusahaan Sektor Pertambangan. Jurnal Sosial Humaniora dan Pendidikan 1, 1.

Pratheepan, T., \& Y.K Weerakoon Banda. (2016). The Determinants of Capital Structure: Evidence from Selected Listed Companies in Sri Lanka. International Journal of Economics and Finance; Vol. 8, No. 2.

Sartono, A. (2014). Manajemen Keuangan Teori Dan Aplikasi Edisi Empat. BPFE.

Sudana, I. (2011). Manajemen Keuangan Perusahaan.

Sugiyono. (2015). Metode Penelitian Pendidikan (Pendekatan Kuantitatif Kualitatif dan R\&D).

Tijow, A., Harijanto Sabijono, \& Victorina Z. Tirayoh. (2018). Pengaruh Struktur Aktiva dan Profitabilitas Terhadap Struktur Modal pada Perusahaan Sektor Barang Konsumsi yang Terdaftar di Bursa Efek Indonesia. Jurnal Riset Akuntansi Going Concern 13(3), 477-488.

Udayani, D., \& I.G.N. Suaryana. (2013). Pengaruh Profitabilitas Dan Investment Opportunity Set Pada Struktur Modal. EJurnal Akuntansi Universitas Udayana 4(2), 299-314.

Yuliani, S. (2011). Pengujian Pecking Order Theory: Analisis Faktor-Faktor yang Mempengaruhi Struktur Modal Industri Manufaktur di BEI Periode Setelah Krisis Moneter. 56-69.

Yusron, H., Deannes Isynuwardhana, \& Dedik Nur Triyanto. (2016). Pengaruh Profitabilitas, Likuiditas dan Ukuran Perusahaan Terhadap Struktur Modal pada Perusahaan Pertambangan Sektor Batubara yang Terdaftar di Bursa Efek Indonesia Tahun 2011-2015. e-Proceeding of Management : Vol.3, No.2, 1596. 